\title{
The Profesionalism Improvements of Catholic Religious Teachers in Jember
}

\section{Petrus Amat Sutadi ${ }^{*}$, Suwognyo Widagdo ${ }^{2}$, Muhaimin Dimyati ${ }^{3}$}

${ }^{123}$ Sekolah Tinggi Ilmu Ekonomi (STIE) Mandala Jember

\section{A R T I C L E I N F O}

\section{Article history:}

Received 19 August 2019 Received in revised form 16 September 2019

Accepted 15 October 2019

Available online 29

November 2019

Keywords:

profesionalism, education and training, teaching

experience, quality

supervision

\begin{abstract}
A B S T R A C T
The quality of teacher, one that can be seen from the professionalism of the teacher. The professionalism of the Catholic religious teachers in Jember can be measured from four factors, such as: trainings, teaching experience, school facilities and the quality of supervisions. Based on the explanation above, the formulation of the problem in teaching, teaching experience, school facilities and the quality of supervision in improving the professionalism of the Catholic religious teachers in Jember. This study aims to examine whether there are influences from trainings, teaching experience, school facilities and quality of supervision in improving the professionalism of the Catholic religious teachers in Jember. The population of this study was Catholic religious teachers in Jember. In this study, researchers will use total sampling. In this study, the researcher sample samples of 30 Catholic religious teachers as respondents, because this study uses multiple linear regression analysis of SPSS version 16 application. Based on data analysis shows that the training has a dominantly significant effect on the professionalism of the improvement of Catholic religious teachers in Jember. Whereas teaching experience, school facilities and infrastructures. and quality of supervision gives a not-yet-dominantly effective improvement to the professionalism of Catholic religious teachers in Jember.
\end{abstract}

\footnotetext{
* Corresponding author.

E-mail addresses: petrusamat@gmail.com (Petrus Amat Sutadi)
} 


\section{Introduction}

Learning is essentially a complex activity, many aspects are interrelated. In learning activities, various components are involved which are interrelated with each other. Among the various components of learning, learning models (strategies and methods) is one component that has a very strategic position and role. In fact, it is a factor that determines the quality of the process and learning outcomes (Arikunto, 1995).

Besides that the components that are not less important are educators, namely about their teaching experience, education and training that has been followed, facilities and infrastructures. The quality of human resources are also greatly influence the success of education in Indonesia.

The purpose of this study are to examine and analyze the influence of variables simultaneous, partial and the most dominant variables of Education and Training, Teaching Experience, infrastructure and quality of supervision on the level of Professionalism of Catholic religious teachers in Jember.

Based on previous research, as conducted by Yuliata Evlyn Anggraeni (2008), states that, the variable completeness of teaching facilities is more influential than others 1.244 . R2 value of 0.72 or $72 \%$ shows a fairly close value to teacher performance. Likewise the research conducted by Rina Wahyuningtyas (2010), states that the independent variables including education, training and teaching experience have a significant influence with the professionalism of economic teachers in Probolinggo District. This is indicated by the amount of $\mathrm{R} 2=0.440$, which means that the contribution of education, training, and teaching experience to the professionalism of economic teachers in the high schools in Probolinggo is $44 \%$ and the rest is $56 \%$ influenced by other variables outside the research model.

The research conducted by Cahyasumirat Gunawan (2015) states that positive professionalism has an effect on performance satisfaction, while organizational commitment has no effect on job performance and satisfaction. In addition, Ahmad Gazali's (2015) research states that Teaching Experience has a positive effect on Teacher Professionalism. The research was also conducted by Yuni Dwi Ambarwati (2017) states that there is a positive effect of Teaching Supervision Contributions, Facilities and infrastructures on Teacher Performance Commitments in Grobogan District High School. The research conducted by Novi Mariyani (2015) states that there is a moderate level of influence between Principal Supervision and Teacher Professional Competence on Teacher Performance at Islamic Middle School in Ciawi Bogor Sub-District in 2015/2016.

The equation with this study is the variables discussed as independent variables are education and training, teaching experience, school facilities and infrastructures as well as the quality of supervision. Having the same goal, namely to find out what variables or dimensions influence the professionalism of teachers, the research uses data collection techniques in the form of questionnaires, observations and interviews. The populations used are the Catholic religious teachers. This research uses a quantitative approach. While the differences are about research locations, number of independent variables or dimensions and the validity testing techniques which using multiple linear regression.

From this background, the purpose of this study was to test and analyze the effect of simultaneous, partial and the most dominant variables of education and training, teaching experience, facilities and infrastructures and quality of supervision on the level of Professionalism of Catholic religious teachers in Jember.

\section{Methods}

Object of research

The object of research was carried out on Catholic Religious Teacher of Elementary School, Junior High School, and Senior High School / Vocational School both in Public and Private Schools in Jember Regency from May to June 2018

Population and Samples

In this study, researchers took a sample of 30 respondents, because this study uses multiple linear regression analysis with the terms five (5) times the number of variables, namely $5 \times 5$ (variables) $=25$ respondents, then the sample of 30 respondents has represented the number of exists samples. The population in this study is the Catholic religion teacher in Jember. In this study, researchers will use saturated sampling.

Research and Measurement Variables

This study consists of two (2) kinds of variables, namely independent variables and dependent variables. In this study the dependent variable is the professionalism of Catholic teachers. Whereas the independent variables are education and training, teaching experience, facilities and infrastructures and quality of supervision. Operational definitions in this study consist of: teacher professionalism with 
indicators of mastery of material, understanding curriculum and understanding of students. Education and training, with indicators of the improvement of ability, attitude and skill. Teaching experience, with indicators the length period of teaching, rank stratification and learning planning. Facilities and infrastructures, with indicators of learning class/room, availability of teaching props and the availability of supporting books. Quality of supervision, with indicators of supervision of the Department of Education, supervision of principals and the periodic assessment.

Analysis Method

The method of data collection used in this study are interview, observation and questionnaire method. The data analysis method used in this study are first: Data Validity Test consisting of 1) Validity Test, 2) Reliability Test, second: Classical Assumption Test which consists of 1) Normality Test, 2) Multicollinearity Test, 3) Heteroscedasticity Test, third: Multiple Linear Regression Analysis, fourth: Hypothesis Test consisting of 1) Multiple Determination Coefficient Test (R2 Test), 2) Simultaneous F Test 3) Partial Test (t Test).

\section{Result and Discussion}

Test the validity of the data using validity and reliability test. Test the validity of the variables of education and training, learning experience, infrastructure and quality of supervision based on the data collected from 30 respondents showed that the items in question correlated significantly to the total score which means declared valid. Testing this validity is done using a one-sided test with a significance level of 0.05 . In this case, $r$ table $=\mathrm{N}$ and $\mathrm{N}=30$ with a significant level $=5 \%$, which is 0.361 .

Reliability test is a continuation of the validity test. The items that included to the test are valid items only. The Alpha formula is used to find the reliability of an instrument which score is not 1 and 0 (Arikunto, 2006: 196). Research Procedure. The reliability test results using SPSS version 16.0 with the Cronbach's Alpha method showed that Cronbach's Alpha value was 0,60 . So it can be concluded that all 42 questions were reliable, those 42 question items, representing 12 indicators, so the questions that would be given to research respondents became 42 questions. The results of the study on the dependent variable is the professionalism of Catholic religious teachers (Y), which was taken through distributing questionnaires, with the number of questions as many as 42 items, using a Likert scale (multiple choice with 5 answer choices).

To carry out the regression analysis and hypothesis testing, the test analysis requirements were carried out previously on the professionalism variables of the Catholic religious teachers (Y), Education and Training (X1), Teaching Experience (X2), Facilities and Infrastructures (X3), Quality Supervision (X4).

The results of the normality test, concluded that Ho is accepted and the normal distribution pattern where the data spreads around the diagonal line or graph histogram. To find out whether multicollinearity is occurring or not, there are several multicollinearity tests. The size of the VIF (Variance Inflation Factor) coefficient is because the VIF coefficient of the Education and training variable (X1) is 8.270; Learning Experience variable (X2) is 2,144; Facilities and infrastructures variable (X3) is 3.771; Supervision variable (X4) of 7.760; is smaller than 10 , so there is no multicollinearity. The number of Tolerance numbers, because the education and training variable tolerance coefficient (X1) is 0.121; Learning Experience variable (X2) is 0.466; infrastructure variable (X3) is 0.265; Supervision (X4) of 0.129; is greater than 10 , so there is no multicollinearity.

To find out whether there is heteroscedasticity or not, there is a spread pattern of points in the scater plot. Singgih Santoso stated that the case of heteroscedasticity can be detected by the presence or absence of a particular pattern of data on the graph, where the $\mathrm{X}$ axis is the predicted $\mathrm{Y}$, and the $\mathrm{X}$ axis is the residual ( $\mathrm{Y}$ prediction - $\mathrm{Y}$ actually) that has been standardized. Based on the results of heteroscedasticity test there is no clear pattern, and the points spread above and below the number 0 on the $\mathrm{Y}$ axis, then Heteroscedasticity does not occur. Singgih Santoso stated that to detect autocorrelation can see the coefficient of Durbin Watson (DW). Because the DW coefficient is 2.757, which is located between -2 to +2 , meaning there is no case of Autocorrelation.

The regression line variance analysis was used to find out how much the regression line interpreted the independent variables consisting of Education and training (X1), Learning Experience (X2), Facilities and infrastructures (X3), Supervision (X4), on the Professionalism of Catholic religious teachers in Jember Regency (Y).

It is known that the coefficient of determination serves to measure the proportion of the contribution of the independent variable $(\mathrm{X})$ to the rise and fall of the dependent variable. Based on the multiple linear regression test, the adjusted R Square value was 0.049 or $0.49 \%$, while the R squared was 0.180 or $18.0 \%$. Thus it can be concluded that $18.0 \%$ that the independent variables include Education and training (X1), Learning Experience (X2), Facilities and infrastructures (X3), Quality Supervision (X4), 
together (simultaneously) explain (influence) changes in the dependent variable towards the professionalism of Catholic religious teachers in Jember Regency (Y) which is equal to $18.0 \%$.

Education and training Variables (X1), Learning Experience (X2), Facilities and infrastructures (X3), Supervision (X4) partially have a partial influence on Teacher Professionals in Catholic religious teachers in Jember Regency (Y). To prove the truth, it needs to be tested using a partial regression test through the $t$ test, where the t test is intended to find out whether the independent variable partially has a significant effect on the dependent variable.

Based on the calculation using the SPSS version 16. The Education and training variables have a $t$ count of -1.080 and a significance value of 0.290 . Learning Experience variable has $t$ count of -0.18 and a significance value of 0.986 . Facilities and infrastructures variables have a $t$ count of -0.567 and a significance value of 0.576 , the Supervision Variable has t count of 0.767 and a significance value of 0.450 .

The $\mathrm{F}$ test is known as a simultaneous test or Anova test. From the results of the above data it can be seen that F-count is smaller than table $1.375<2.76$. So the conclusion is independent variables in the form of supervision, teaching experience and education and training simultaneously influence the dependent variable, namely the professionalism of Catholic teachers. Based on the significance of the significance value is $0.271>0.05$, then the independent variables in the form of supervision, teaching experience, education and training together have a significant effect on the dependent variable, namely the professionalism of Catholic teachers.

The results of this study indicate that significant education and training, teaching experience, Facilities and infrastructures, and quality of supervision have an influential but not dominant influence on the professionalism of Catholic religious teachers in Jember Regency. Because Education and training, teaching experience, Facilities and infrastructures and quality of supervision are considered low, it does not improve the professionalism of Catholic religious teachers in Jember Regency.

Variable (X1) namely Education and Training is the most dominant which is able to explain the variation of Y by $-0,383$ or $38.3 \%$. While the teaching experience variable (X2) has not been able to explain the variation of $Y$ which only has a calculated value of -0.181 or equal to $18.1 \%$.

\section{INTERPRETATION}

From the regression analysis the results showed that education and training had a significant effect but did not become the dominant influence on the professionalism of Jember Catholic religious teachers with a significance of 0.290 with an alpha value of $\leq 0.05$. This means that the school's efforts to conduct education and training have not been able to improve the professionalism of Catholic religious teachers in Jember Regency. Based on the explanation above, it can be said that the better education and training, the more influential simultaneously but does not partially affect the professionalism of Catholic religious teachers in Jember Regency and vice versa.

The teaching experience is influential but does not have a dominant effect on the professionalism of Catholic religious teachers in Jember Regency with a significance of 0.986 with an alpha value of $\leq 0.05$. The results of this study indicate that teaching experience has no effect on professionalism in Jember Regency. Because the teaching experience was considered low by respondents, it did not increase professionalism in Jember Regency. This means that schools and teachers must improve their professionalism and pedagogical abilities in order to increase their professionalism. Based on the explanation above, it can be said that the better the teaching experience, has a simultaneous effect but does not partially influence the increasing professionalism of Catholic religious teachers in Jember Regency.

Facilities and infrastructures do not have a dominant influence on the professionalism of Catholic religious teachers in Jember Regency with a significance of 0.576 with an alpha value of 50.05 . This means that school efforts to improve professionalism and pedagogical abilities have not been able to improve the professionalism of Catholic religious teachers in Jember Regency. Based on the explanation above, it can be said that the better the facilities and infrastructures, have a simultaneous effect but does not partially affect the professionalism of Catholic religious teachers in Jember Regency.

The quality of supervision is influential but not dominant on the professionalism of Catholic religious teachers in Jember Regency with a significance of 0.450 with an alpha value of $\leq 0.05$. This means that the quality of supervision cannot increase the professionalism of Catholic religious teachers in Jember Regency. Thus, the better the quality of supervision has an effect simultaneously but does not partially affect the professionalism of Catholic religious teachers in Jember Regency. 


\section{Conclusion}

Simultaneously education and training, teaching experience, facilities and infrastructures and quality of supervision have a significant effect on the professionalism of Catholic religious teachers in Jember Regency. Partially education and training, teaching experience, facilities and infrastructures and quality of supervision have a significant but not dominant influence on the professionalism of Catholic religious teachers in Jember Regency. While education and training is the dominant variable affecting teacher professionalism.

The influence education and training, teaching experience, facilities and infrastructures and quality of supervision are factors that influence the professionalism of Catholic religious teachers in Jember Regency, and education and training are the most dominant factors affecting the professionalism of Catholic religious teachers in Jember Regency. Then there is a need for continuous guidance so that other factors can further enhance the professionalism of Catholic religious teachers in Jember Regency.

\section{Reference}

Anggaeni, Yulita Evly, 2008. Pengaruh Latar belakang Pendidikan, Pengalaman Mengajar, dan Kelengkapan Sarana Pembelajaran terhadap Kinerja Guru di SMP Muhamadiyah 5 Surakarta Skripsi Universitas Mumamadiyah Surakarta.

Arikunto, Suharsini 2006, Prosedur Penelitian Suatu pendekatan Praktik, Jakarta : Rineka Cipta

Aqib, Zaenal 2009, Menjadi Guru Profesional Berstandarc Nasional , Bandung : Yrama Widya

Bafadal, Ibrahim 2008, Peningkatan Profesionalisme Guru Sekolah Dasar. Jakarta: Bumi Aksara.

Bastaman, A. tt. Metode Pembelajaran P rktik Lapangan. Bogor : Balai Diklat Kehutanan.

Danim, Sudarwan, 2010. Pedagogi, Androgogi dan Heutorologi. Bandung. Alfabeta.

De Porter, B Reardon, M \& Nourine, S. S, 2002. Quantum Teaching, Memparktikan Quantum Learning di ruang - ruang kelas. Bandung : Kaifa.

De Porter, B \& Hernachi, M, 2007. Quantum learning : Membiasakan Belajar Nyaman dan menyenangkan. Cetakan XXIV. Bandung : Kaifa.

Gozali. Imam, 2013. Aplikasi Analisis Multivariate dengan Program IBM SPSS 21. Semarang. Badan Penerbit Undip.

Isjoni. 2007. Dilema Guru Ketika Pengabdian Menuai kritikan. Bandung : Sinar Baru Algensindo.

Kaufeld, M. 2008. Wahai Para Guru Ubahlah Cara Mengajarmu! Jakarta. PT Indeks.

Kementerian Komunikasi dan Informatika Republik Indonesia 2010. Mendiknas Buku pelatihan Guru Internasional negara E-9. Availabe at http://www.depkominfo.go.id/berita/bipnewsroom/mendiknas-buka-pelatihan-guruinternasional-negara-e-9

Mulyasa, 2011. Menjadi Guru Profesional Menciptakan Pembelajaran Kreatif dan Menyenangkan. Bandung : remaja Rosdakarya.

Munif, Akhmad dkk, 2007. Pengantar Ilmu Pendidikan. Semarang : Universitas Negeri Semarang Press.

Pidarto, Made. 2007. Landasan kependidikan. Jakarta : Rineka Cipta.

Priyansyah, Yudi. 2009. Tujuan dan Manfaat pelatihan. Online http://infointermedia.com/tujuan-danmanfaat-pelatihan. 
Priyatno, Duwi. 2010. Teknik Mudah dan Cepat Melakukan Analisa Data Penelitian dengan SPSS dan Tanya jawab Ujian Pendadaran. Yogyakarta : Gava Media.

Riduwan, 2008. Belajar Mudah Penelitian untuk Guru- Karyawan dan Peneliti Pemula.Bandung : Alfabeta.

Sagala, Syaiful 2009. Kemampuan Profesional Guru dan Tenaga Kependidikan. Bandung. Alfabeta.

Soetjipto dan Raflis Kosari. 2004 Profesi Keguruan. Jakarta : Rineka Cipta.

Sugiyono, 2008. Metode Penelitian Kuantitatif, Kualitatif dan R\& D. Bandung : Alfabeta.

Wahyuningtyas, Rina 2010. Pengaruh Tingkat Pendidikan, Pelatian dan Pengalaman Mengajar Terhadap Profesionalisme Guru Ekonomi di SMA se- Kota Probolinggo, Skripsi Universitas Negeri Malang. 